\title{
北海道における軽種馬産地の変化
}

\section{Changes in Race Horse Production in Hokkaido}

\author{
沼田 尚也* \\ Naoya NUMATA*
}

キーワード：軽種馬生産，高品質化，国際化，北海道

Key words : Race horse production, quality improvement, internationalization, Hokkaido

\section{I . 馬産地形成の歴史的側面}

北海道は2000年現在，日本国内で生産される軽 種馬の $95.0 \%$ 以上を生産する（図 1)。北海道内 における軽種馬の産地である日高・胆振・十勝地 方は，夏季の最高気温が $25^{\circ} \mathrm{C}$ 超えるものの，酷 暑となることは少ない。また, 冬季も $-10^{\circ} \mathrm{C}$ 以下 には滅多にならず, さらに雪が少ないなど, 馬産 地形成の基底条件となる自然環境は, 軽種馬の生 産・放牧に適しているといえる。

北海道に扔ける馬産地形成の歴史をみると, 古 くは1858年（安政 5 年）に日高地方の元浦河に幕 府直轄の馬牧が設置されている（田林, 1998 ; 岩 崎，2005）。また，1872年（明治 5 年）に開拓使 により新冠に牧場が開設され（1888年より新冠御 料牧場），1907年には内閣直属の日高種馬牧場が 創設されるなど, 明治時代から馬産研究施設が開

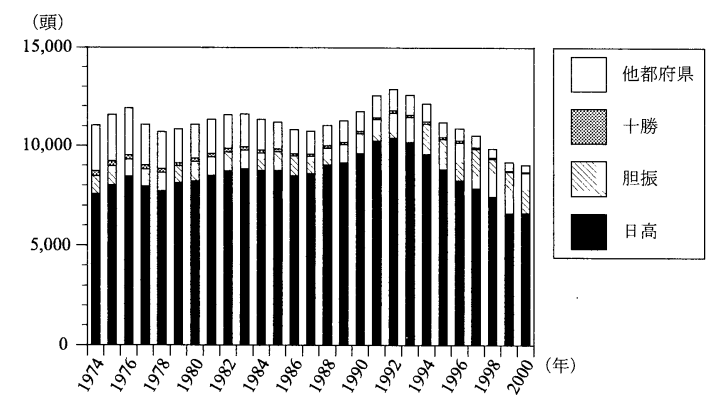

図 1 種牡馬供用地域別生産頭数の推移 (サラ・アラ 合計）

軽種馬生産統計より作成。
設されている（進藤, 1977 ; 田林, 1998）。胆振 地方も, 1900年代初頭から軍馬育成によって馬産 地の素地があった。しかし, 軽種馬生産が本格化 したのは, 軽種馬市場の拡大がはじまる第二次世 界大戦後, 1948年の競馬法制定以降である。特に 1965年以降, 高度経済成長に伴って競馬ブームが 起き, 軽種馬飼養農家が増加した経緯がある（田 林, 1998)。

北海道の軽種馬産地については, これまでも 新藤（1977）や田林（1998）をはじめとして, 地 理学的な調査が行われてきた。ただし，従来の研 究は日高地方に招ける軽種馬生産に焦点が当てら れ，他の地域との比較が行われたわけではない。 本稿では, 胆振地方における動向を視野に入れつ つ, 北海道における軽種馬生産の変化について, 予備的な考察を示したい。

\section{II. 生産数の推移亡地域別の特色}

図 1 は, 1970年代からの種牡馬供用地域別の生 産数および地域別の生産割合の推移を示したもの である。軽種馬の生産数は, バブル期までは横ば いから微増傾向にあったが, バブル崩壊以後は減 少傾向にある。また，1990年代からは，競馬の国 際化の下に中央競馬における外国産馬への門戸開 放が行われている。さらに，2001年の中津競馬廃 止を皮切りに, 軽種馬生産を底辺から支えていた 地方競馬の廃止が相次いでおり, 景気の動向とと もにこれらの影響も生産数に反映されていること

\section{*俱知安町}

${ }^{*}$ Kutchan Municipal Office 
表 1 地域別牧場数および 1 牧場あたりの生産頭数 (2003年)

\begin{tabular}{lccccc}
\hline \hline & 日高 & 胆振 & 十勝 & 他都府県 & 全国 \\
\hline 牧場数 & 1107 & 89 & 32 & 240 & 1468 \\
$\begin{array}{l}\text { 1牧場あたりの } \\
\text { 生産頭数 }\end{array}$ & 6.36 & 12.37 & 3.22 & 2.12 & 5.96 \\
\hline
\end{tabular}

表 2 種雌馬飼養規模別牧場数 (2003年)

\begin{tabular}{lccccc}
\hline \hline & 日高 & 胆振 & 十勝 & 他都府県 & 全国 \\
\hline $1 \sim 5$ 頭 & 411 & 43 & 24 & 197 & 675 \\
$6 \sim 10$ 頭 & 398 & 18 & 6 & 26 & 448 \\
$11 \sim 15$ 頭 & 184 & 15 & 1 & 12 & 212 \\
$16 \sim 50$ 頭 & 109 & 8 & 1 & 5 & 123 \\
$51 \sim 100$ 頭 & 5 & 2 & 0 & 0 & 7 \\
101 頭以上 & 0 & 3 & 0 & 0 & 3 \\
\hline 合計 & 1107 & 89 & 32 & 240 & 1468 \\
\hline & & & \multicolumn{3}{c}{ 2003年軽種馬統計より作成。 }
\end{tabular}

がうかがえる。

軽種馬の生産拠点は, ここ30年の間に北海道外 での生産数・割合ともに大きく減少しており, 1988年以降は北海道のシェアが90.0\%を超えてい る。なお，道内では依然として日高地方におけ る生産数が多い。しかし，1992年を境に，日高地 方における生産は減少の一途をたどっている一 方で，1992年までは全体の10.0\%未満であった胆 振地方（以下隣接する千歳市も含む）のシェア が，近年では増加傾向にあり，2000年には全体の $22.0 \%$ 占めるようになっている。

また，牧場の規模も地域によって差が生じてい る。表 1 は2003年における地域別の牧場数および
1 牧場あたりの生産頭数を示している。生産頭数 と同じく日高地方の牧場数は圧倒的に多いが，1 牧場あたりの生産頭数は胆振地方が非常に多い。 これは, 胆振地方における軽種馬生産が大規模か つ集約的な特徴を持っていることを示している。 これをさらに詳しく示したものが表 2 である。牧 場の規模を端的に示す種雌馬飼養数を元に地域ご との経営規模をみると, 胆振地方には101頭以上 の種雌馬を飼養する牧場もあり，大規模な牧場の 数・割合がともに高いことがわかる。これは，胆 振地方の軽種馬生産が, 競馬の国際化への対応を 考慮して，経営を変化させてきたことによる。な 押，胆振地方には，現在の日本の競馬界を牽引す

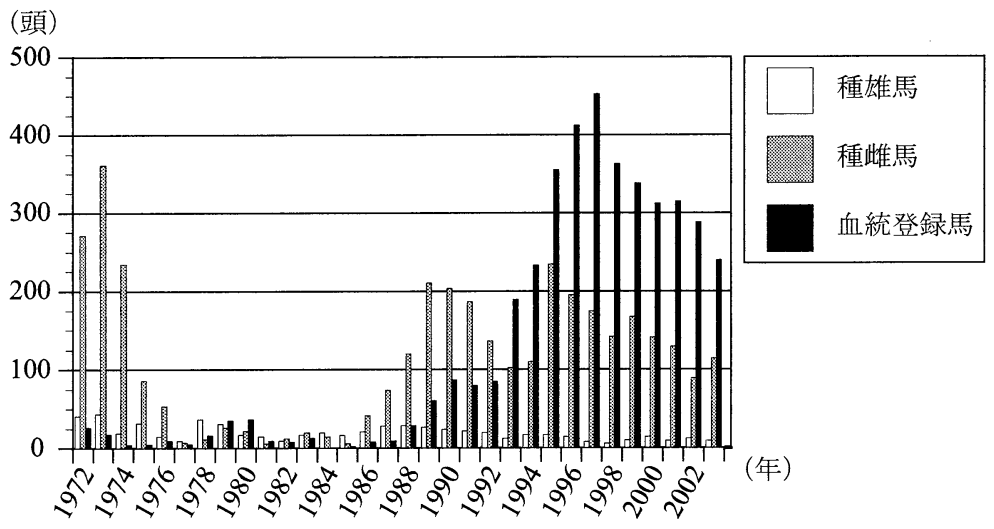

図 2 年次別輸入頭数 (サラ・アラ合計) 2003年軽種馬統計より作成。 
る社台グループの牧場が点在するほか, メジロ牧 場や西山牧場といった大規模な牧場が立地する。

図 2 は軽種馬の年次別の輸入頭数を示したもの になる。これによると，1992年より始まった中央 競馬の国際化計画による外国産馬の出走制限緩和 以降, 血統登録馬（競走用の馬）の輸入が増えて いることがわかる。これにより，長らく日本競馬 界によって守られてきた日本の軽種馬生産は国際 化の時代に入ったといえる。なお, 近年, 外国産 馬の輸入が落ち着いてきた理由としては, 景気の 変動の他に, 国内の軽種馬生産が外国産馬に対抗 できる競争力をつけてきたことが考えられる。し かし, その過程で有力種牡馬の保持や高度育成シ
ステムの形成により, 大規模牧場と零細牧場とい う生産サイドの 2 極化が進展した。

\section{III. 胆振地方の軽種馬生産の高品質化}

日本の競馬には，賞金額や出走馬の質が高い中 央競馬と, 軽種馬生産を底辺から支える地方競馬 の 2 つがある。中央競馬の中で最も格が高く, 限 られた一流馬しか出走できない, 日本の競馬の頂 点に立つレースが中央競馬G 1 レースである ${ }^{1)} 。$

図 3 は, 胆振・日高・十勝地方における牧場の 立地を示すと同時に, 各牧場で生産した軽種馬の 中央競馬におけるG1 レース勝ち鞍数を示してい る。これによると, 軽種馬生産牧場は, 日高地方

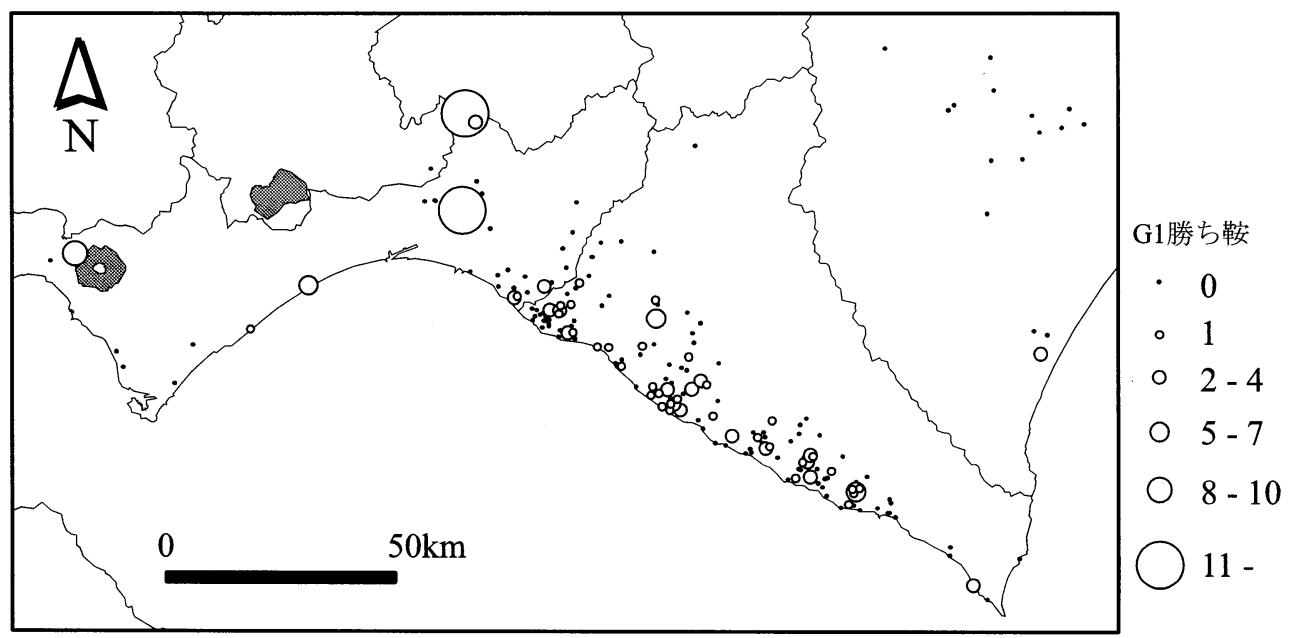

図 3 軽種馬生産牧場の分布 (2005年)

円の大きさは1996年〜2005年の中央競馬 G 1 レースにおけるのべ勝ち鞍数による。

電話帳，北海道馬産地図，中央競馬会資料より作成。

表 3 中央競馬 G 1 レース (1996年〜2005年)勝ち馬の地域別生産投数

\begin{tabular}{ccccccc}
\hline \hline 日高 & 胆振 & 十勝 & (外国産馬・外国馬) & その他 & 計 \\
\hline 67 & 59 & 2 & 51 & 1 & 180 \\
\hline
\end{tabular}

中央競馬会資料より作成。

レース時にG 1 レースであり，外国産馬が1頭でも出走可能なレースについて集計

表 4 地域別種牡馬・種雌馬種付け頭数 (2003年)

\begin{tabular}{lrrccc}
\hline \hline & 日高 & 胆振 & 十勝 & 他都府県 & 全国 \\
\hline 種牡馬数 & 260 & 45 & 15 & 69 & 389 \\
種付け頭数 & 8024 & 3711 & 74 & 494 & 12303 \\
一頭あたりの種付け頭数 & 30.86 & 82.47 & 4.93 & 7.16 & 31.63 \\
\hline & \multicolumn{4}{c}{2003 年軽種馬統計より作成。 }
\end{tabular}


に多くが分布するが, 胆振地方にはG1レース勝 ち鞍数が他と比べて非常に多い牧場が存在する。 さらに表 3 はこれを生産地域別にまとめたもので ある。軽種馬の生産頭数は圧倒的に日高地方が多 く（図 1)，牧場も多いが, 頂点のレースのみを みると胆振地方と外国産馬の割合も高いことがわ かる。これは, 胆振地方の軽種馬生産が外国産馬 への対抗を念頭に置いて, 軽種馬の高品質化に力 を注いだ結果である。

価值の高いレースで好走した馬は, 引退後も有 力な種牡馬になることが多い。胆振地方は大きな レースで好走した後に種牡馬となった馬が多く, さらに海外から有力種牡馬も導入している。その

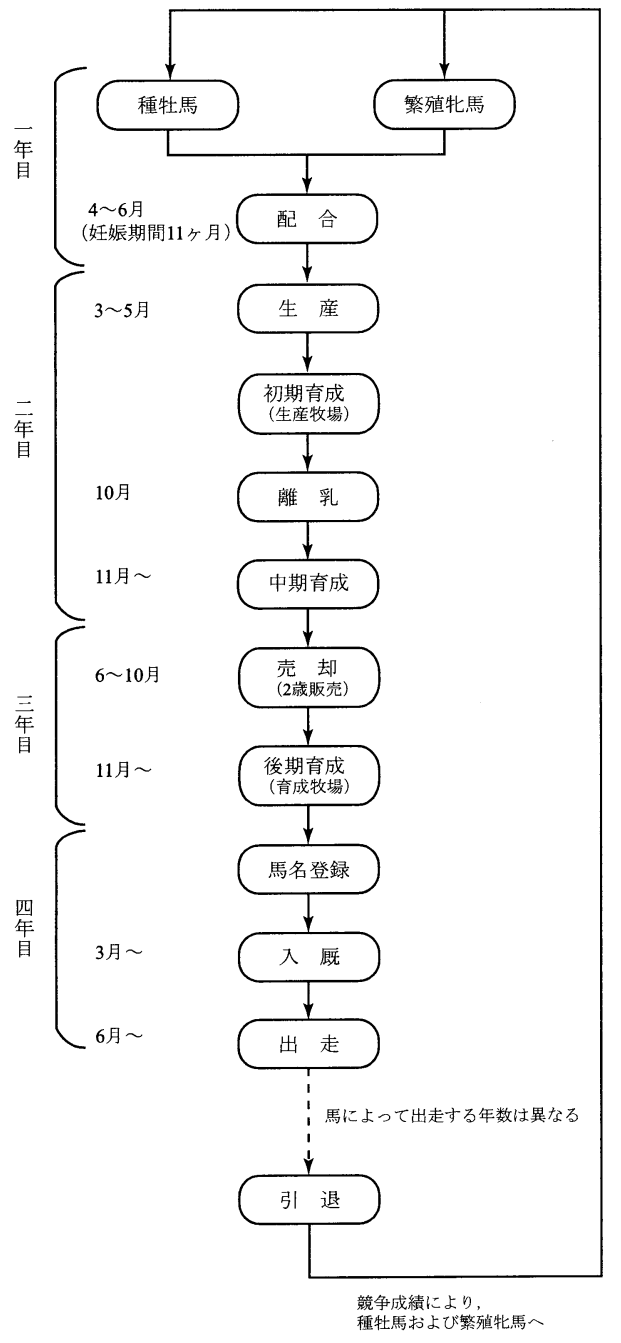

図 4 軽種馬生産のサイクル 小山（2004）上り筆者作成。
ため, 表 4 に示したとおり, 種牡馬数に対して種 付けする繁殖牝馬が多く, 種牡馬一頭あたりの種 付け数が多い。ちなみに, 日高など他の地方から も胆振地方の有力な種牝馬への種付けは数多く存 在する。

出生した軽種馬には, 出走までに数段階の育 成が施される（図 4)。近年の競馬では，よい血 統により優秀な馬を生産するとともに, 生産後の 初期育成も後の成績を決める重要な要因となる。 胆振地方に存在する大規模牧場では高度育成シス テムの形成により, 効果的に育成が進められてい る。さらに, 大規模牧場のいくつかは, 有力馬主 との良好な関係や安定した需要確保のためのクラ ブ法人（一般に一口馬主と呼ばれる小口の出資に よる会員を募った愛馬会法人より，馬の現物出資 を受ける法人馬主）の所有もあり経営の安定が図 られている。

近年の軽種馬産地では, バブル崩壊以後の景気 の低迷と競馬の国際化，地方競馬の撤退に端をな して大規模牧場と零細牧場という生産者の 2 極化 の進展がうかがえる。これが, 零細牧場が多い日 高地方への軽種馬生産の一極集中が緩むことと， 大規模牧場が立地する胆振地方での生産割合の増 大に繋がっており，北海道内における軽種馬生産 は変化しつつある。

\section{注}

1）中央競馬では，2007年より国際的な規格統一のため に，国際的な格付けがなされているレースに対してグ レード（G）の表記を用い，それ以外をJpnと表記し ている。ただし，本稿はそれ以前のデー夕を用いてい るため, 2006年以前のグレード制を基準とした集計を 行っている。

\section{参考文献}

岩崎 徹 (2005)：『馬産地80話一日高から見た日本競馬 一』北海道大学出版会.

小山良太 (2004)：『競走馬産業の形成と協同組合』日本経 済評論社.

進藤賢一(1977)：日高地方における軽種馬の生産構造. 北 海道地理, 51,13-19。

田林 明(1998)：北海道日高地方における軽種馬生産地域 の構造. 人文地理学研究, 22,79-98.

リンクパブリケーション (2006)：『北海道馬産地・図 vol.1』リンクパブリケーション . 